\title{
The Relationship between Body Composition and Physical Fitness Parameters in Children
}

\author{
Nebahat Eler ${ }^{1}$ \\ ${ }^{1}$ Physical Education and Sports, Bulent Ecevit University, Zonguldak, Turkey \\ Correspondence: Nebahat Eler, Physical Education and Sports, Bulent Ecevit University, Zonguldak, Turkey. Tel: \\ 90-505-737-2853. E-mail: nebahateler@gmail.com
}

Received: May 31, 2018

doi:10.5539/ies.v11n9p71
Accepted: July 2, $2018 \quad$ Online Published: August 28, 2018

URL: https://doi.org/10.5539/ies.v11n9p71

\begin{abstract}
The aim of this study is to analyze the relationship between body composition and physical fitness parameters in children. 286 male and 311 female students have voluntarily participated in the study. Data on body composition have been obtained through the measurements of the students' height, body weight, BMI, body fat percentage, length (sitting height, arm length, forearm length, leg length, thigh lengths), circumference (elbow, shoulder, biceps (flexion), buttock, knee, waist, calf, ankle). For somatotype characteristics, the Heat-Carter somatotype grading method has been used. The Sit-Reach Flexibility Test $(\mathrm{cm})$ has been used to determine the characteristic of flexibility; the $20 \mathrm{~m}$. Speed Test (seconds) to determine speed; the $20 \mathrm{~m}$. Sit-up test to determine endurance; Takkei hand dynamometer to determine right-left hand grip strength; Takkei back and lift dynamometer for leg strength and the Flamingo Balance Test for balance have been used. In the analysis of data, the SPSS 16 software has been used and $\mathrm{T}$ test and Pearson correlation test have been carried out $(\mathrm{p}<0.05)$. Between the body composition and physical fitness parameters of female and male students, a statistically significant relationship has been found with the exception of age, arm and waist measurements $(\mathrm{p}<0.05)$. In both genders, positive or negative relationships have been found between height, circumference measurements and somatotype characteristics and performance tests $(\mathrm{p}<0.05)$. It was found that there is a negative or positive relationship between the heights, circumference measurements and somatotype characteristics and their strength, endurance, speed, flexibility and balance characteristics of female and male children aged 10-12. As a result, it has been seen that the body composition of children aged 10-12 affects the physical fitness parameters. Children in this age group which is both a period of growth and development and skills selection period for numerous sports branches should regularly be followed by their physical education teachers, anthropometric measurements and performance tests should be carried out and the children should be directed towards suitable sports branches.
\end{abstract}

Keywords: body composition, anthropometry, somatotype, physical fitness, children

\section{Introduction}

Even if children are the same age, the body type, physical fitness levels, motivations, skills, learning speed, past experiences and family environments are different from one another (K. Özer \& D. Özer, 2000). In particular, body composition constantly changes throughout childhood and teenage periods.

There is a strong relationship between physical activity and body composition (Reicherte et al., 2012). The general aim of studies on body height, structure and composition is to determine and develop physical fitness individually (Artioli et al., 2008). Since there is a relationship especially between body height and many physical and physiological characteristics, these display significant effects on exercise and certain games (Docherty, 1996). Regular exercise has positive effects on children's somatotype classifications and anthropometric characteristics (Berg et al., 1995) and suitable anthropometric profile and body composition for physical activity are important (Canhadas et al., 2010). Identification of somatotype during childhood is extremely important for skills selection because determining the body shape makes it possible for the emergence of children's tendency in the sports branch to be participated in the future and competing in an advantageous position in terms of displaying a high performance.

Regular physical activity plays an important role in improving and preserving human health and is necessary for the growth and development of children as well (Cordova et al., 2012). While the body compositions of individuals who are physically active are better, they also have less health problems. Decrease in the number of physical 
activities and some physical and physiological changes in the teenager years such as pubertal growth spurt show that determining the body structure of children carries great importance (Çolak \& Yiğit, 2017). In addition, the strength of heart-respiratory systems, muscle power and strength, body shape and flexibility depend on the state of physical fitness which is related to health (Oğuzhan et al., 2014). Body shape is closely correlated with health, blood pressure increases with the increases of body mass and waist-to-hip ratio, and it is more obvious in males than in females, the body mass and waist-to-hip ratio (Shahtahmasebi \& Cassidy, 2015).

The aim of this study is to analyze the relationship between the body composition and physical fitness parameters of female and male children aged 10-12.

\section{Method}

\subsection{Participants}

A total of 597 students between the ages of 10 and 12 (286 female, 311 male) participated in this study voluntarily in Ankara. The families of the students and their schools' administrations have been informed in detail about the study and their approval was received.

\subsection{Anthropometric Measurements}

The students' weight measurement has been done with a sensitive digital scale whose sensitivity level is $0.1 \mathrm{~kg}$. And height measurements were done with a health scale of $0.01 \mathrm{~m}$. sensitivity and BMI has been calculated with the body weight $(\mathrm{kg}) /$ body height $\left(\mathrm{m}^{2}\right)$ formula. Skinfold measurement was taken from the sub-scapula, triceps, biceps, suprailiac, and calf skinfold area. The body fat percentage was calculated with the Durning-Womersley formula. For length and circumference measurements, Holtain anthropometric set was used and sitting height, arm, forearm, leg, thigh lengths and circumference of the elbows, biceps (flexion), shoulder, waist, buttock, calf, knee and ankle were measured. The Heath-Carter Anthropometric Somatotype Rating method was used to determine somatotype.

\subsection{Physical Fitness Measurements}

Prior to the physical fitness tests, the students did warm-up exercises for 10 minutes. Each test was carried out twice (except for the $20 \mathrm{~m}$. Shuttle run) and the best value has been recorded.

The Sit-Reach (cm.) was applied to measure flexibility; the subject flexed his two hands in the front in the sitting position, remained motionless in the furthest point and the distance was recorded. Speed was measured with the 20 $\mathrm{m}$. Speed Test (seconds); the subjects ran for 20 meters with maximal speed from the start line when the start sign was given. The time between start and finish was determined with photocell (New Test 2000). In order to determine endurance, the $20 \mathrm{~m}$. Shuttle (endurance) test was applied once on a different day. The obtained scores were calculated with the help of a rating scale over the subjects' maximum oxygen consumption $\left(\max \mathrm{VO}_{2}\right)$ values $\mathrm{ml} /$ kilogram/minutes (Günay et al., 2013). For the right-left hand grip strength, a hand dynamometer was used and it was applied after it was arranged in accordance with the hand of the subject and the measurement was taken without the subject bending his elbow by applying grip strength. The leg strength was measured with Takkei back and lift dynamometer. After the subjects bent their knees and placed their feet on the dynamometer table, they seized and pulled the dynamometer bar vertically with stretched arms, straight back and slightly bent body towards the front by suing their legs in the maximum amount and the value was recorded. Lastly, the Flamingo Balance Test was used to measure balance; the subject tried standing on the balance board for one minute on his dominant foot with his shoe on and the trial number was determined. The students did 10 minutes of warm up exercises prior to the tests. Other than the $20 \mathrm{~m}$. shuttle run, all of the tests were applied twice and the best value was recorded.

\subsection{Statistical Analysis}

In the analysis of data, the SPSS 16 software was used. In all of the parameters, $t$ test was applied in the dependent and the independent groups to determine the differences between the genders $(p<0.05)$. The normality of data was checked and data was used to analyze the relationships between 2D:4D and physical fitness parameters and 2D:4D and anthropometrical measurements through the Pearson correlation and standardized linear regression coefficients. Since there were more than 50 participants in the data set, all data was tested for normality with Kolmogorov-Smirnov. In order to determine significance, a significance level of $\mathrm{p}<0.05$ was used as criteria. 


\section{Results}

Table 1 . The body composition values of female and male students

\begin{tabular}{lcccccc}
\hline & \multicolumn{7}{c}{ Male $(\mathrm{n}-286)$} & \multicolumn{7}{c}{ Female $(\mathrm{n}-311)$} & & \\
\hline & Mean & SD & Mean & SD & $\mathrm{t}$ & $\mathrm{p}$ \\
\cline { 2 - 7 } Age & 11.21 & 1.03 & 11.36 & 0.23 & -1.71 & 0.08 \\
Height & 142.24 & 9.14 & 144.18 & 6.92 & -2.45 & $0.01^{*}$ \\
Body Weight & 41.11 & 10.23 & 44.87 & 8.95 & -4.76 & $0.00^{*}$ \\
BMI & 21.81 & 5.23 & 22.84 & 6.95 & -2.05 & $0.04^{*}$ \\
Body Fat Percentage & 23.96 & 7.89 & 25.52 & 9.51 & -3.12 & $0.01^{*}$ \\
Length measurements (cm) & & & & & & \\
Sitting height (bust length) & 77.6 & 2.71 & 77.4 & 3.52 & -4.29 & $0.00^{*}$ \\
Arm & 55.3 & 4.41 & 56.2 & 5.18 & -2.29 & 0.02 \\
Forearm & 22.3 & 1.21 & 23.18 & 1.84 & -6.95 & 0.06 \\
Leg & 70.29 & 4.65 & 72.8 & 3.35 & -4.51 & $0.01^{*}$ \\
Thigh & 38.79 & 3.73 & 40.12 & 4.11 & -3.21 & 0.71 \\
Circumference measurements (cm) & & & & & & \\
Elbow & 8.95 & 0.43 & 9.97 & 0.56 & -25.07 & $0.00^{*}$ \\
Shoulder & 69.72 & 3.83 & 70.8 & 1.83 & -4.33 & $0.00^{*}$ \\
Biceps (flexion) & 17.17 & 1.64 & 18.36 & 2.05 & -7.86 & $0.00^{*}$ \\
Waist & 57.72 & 7.84 & 59.11 & 9.76 & -1.92 & $0.04^{*}$ \\
Buttock & 78.12 & 7.94 & 80.24 & 10.33 & -2.82 & $0.00^{*}$ \\
Calf & 27.4 & 2.41 & 28.7 & 6.06 & -3.49 & $0.00^{*}$ \\
Knee & 13.26 & 1.81 & 14.14 & 3.16 & -4.21 & $0.00^{*}$ \\
Ankle & 11.18 & 0.93 & 12.09 & 0.87 & 0.08 & 0.35 \\
Somatotype & & & & & & \\
Endomorphy & 3.42 & 0.07 & 4.96 & 0.08 & 1.3 & $0.02^{*}$ \\
Mesomorphy & 4.11 & 0.61 & 3.65 & 1.14 & -3.13 & $0.00^{*}$ \\
Ectomorphy & 3.34 & 1.08 & 3.96 & 1.43 & -6 & $0.00^{*}$ \\
\hline *P $<0.05$. & & & & & &
\end{tabular}

With the exception of age and arm, forearm, leg, thighs and ankle circumference measurements, a statistically significant differences was found between male and female students in all parameters $(p<0.05)$.

Table 2. The physical fitness values of female and male students

\begin{tabular}{lcccccc}
\hline & \multicolumn{7}{l}{ Male (n-286) } & \multicolumn{7}{l}{ Female (n-311) } & & \\
\hline & Mean & SD & Mean & SD & t & p \\
\cline { 2 - 7 } Flexibility $(\mathrm{cm})$ & 14.2 & 5.94 & 15.41 & 4.48 & -2.82 & $0.00^{*}$ \\
max $\mathrm{VO}_{2}(\mathrm{ml} . \mathrm{kg} / \mathrm{min})$ & 32.8 & 4.23 & 31.3 & 5.41 & 3.78 & $0.00^{*}$ \\
Vertical jump (cm) & 18.12 & 5.68 & 17.74 & 4.09 & 36.47 & $0.00^{*}$ \\
20 m speed (sec) & 4.36 & 0.34 & 4.76 & 0.48 & -11.82 & $0.00^{*}$ \\
Right hand grip strength $(\mathrm{kg})$ & 18.41 & 4.43 & 15.3 & 5.36 & 7.68 & $0.00^{*}$ \\
Left hand grip strength $(\mathrm{kg})$ & 14.12 & 5.12 & 12.94 & 6.19 & 2.54 & $0.00^{*}$ \\
Leg strength & 37.12 & 8.11 & 31.11 & 10.13 & 8.03 & $0.00^{*}$ \\
Balance & 9.38 & 5.36 & 8.21 & 7.41 & 2.22 & $0.02^{*}$ \\
\hline$*$ P $<0.05$. & & & & & &
\end{tabular}

The male students' max $\mathrm{VO}_{2}$, vertical jump, right-left hand grip strength, leg strength and speed parameters were found to be higher compared to female students; the female students' flexibility and balance parameters were found to be higher than the male students (Table 2) and a statistically significant relationship has been found between them $(\mathrm{p}<0.05)$. 
Table 3. The relationship between the physical fitness and body compositions of female students

\begin{tabular}{|c|c|c|c|c|c|c|c|}
\hline & \multicolumn{7}{|c|}{ Female } \\
\hline & Flexibility & $\max \mathrm{VO}_{2}$ & $\begin{array}{l}20 \mathrm{~m} \\
\text { speed }\end{array}$ & $\begin{array}{l}\text { Right hand grip } \\
\text { strength }\end{array}$ & $\begin{array}{l}\text { Left hand grip } \\
\text { strength }\end{array}$ & $\begin{array}{c}\text { Leg } \\
\text { strength }\end{array}$ & Balance \\
\hline & $\mathrm{cm}$ & $\mathrm{ml} . \mathrm{kg} / \mathrm{min}$ & $\mathrm{sec}$ & $\mathrm{kg}$ & $\mathrm{kg}$ & $\mathrm{kg}$ & \\
\hline Height (cm) & $-0.49 *$ & 0.03 & $-0.35^{*}$ & $0.36^{*}$ & $0.42 *$ & $0.25^{*}$ & $-0.49 *$ \\
\hline Body weight (kg) & -0.08 & 0.13 & -0.18 & $0.55^{* *}$ & $0.35^{*}$ & 0.03 & $-0.35 *$ \\
\hline BMI $\left(\mathrm{kg} / \mathrm{m}^{2}\right)$ & -0.09 & $-0.26^{*}$ & -0.19 & $0.58 * *$ & $0.27 *$ & 0.14 & 0.06 \\
\hline Body fat percentage (\%) & 0.04 & $-0.36^{*}$ & 0.05 & $0.71 * *$ & $0.39^{*}$ & 0.11 & $-0.34 *$ \\
\hline \multicolumn{8}{|l|}{ Length measurements (cm) } \\
\hline Sitting height (bust length) & $-0.51 * *$ & 0.15 & $-0.49 * *$ & $0.58 * *$ & $0.51 * *$ & $0.37 *$ & $-0.33 *$ \\
\hline Arm & $-0.58 * *$ & 0.03 & $-0.55^{*}$ & $0.45^{*}$ & $0.56^{* *}$ & 0.03 & -0.11 \\
\hline Forearm & $-0.55^{* *}$ & 0.07 & $-0.45^{*}$ & $0.41 *$ & $0.41^{*}$ & $0.26^{*}$ & -0.16 \\
\hline Leg & 0.02 & 0.04 & $-0.61 * *$ & $0.35^{*}$ & $0.47 *$ & $0.45^{*}$ & $-0.39 *$ \\
\hline Thighs & 0.06 & 0.06 & $-0.39 *$ & $0.41 *$ & $0.45^{*}$ & $0.36^{*}$ & $-0.33^{*}$ \\
\hline \multicolumn{8}{|c|}{$\begin{array}{l}\text { Circumference measurements } \\
\text { (cm) }\end{array}$} \\
\hline Elbow & 0.09 & 0.11 & 0.28 & $0.42 *$ & $0.48^{*}$ & $0.31 *$ & 0.04 \\
\hline Shoulder & 0.12 & 0.06 & 0.09 & $0.40 *$ & $0.55 * *$ & 0.07 & 0.09 \\
\hline Biceps (flexion) & 0.014 & 0.02 & $-0.53^{*}$ & $0.51 * *$ & $0.47^{*}$ & $0.43^{*}$ & 0.16 \\
\hline Waist & 0.03 & 0.03 & 0.11 & 0.17 & 0.13 & $0.26^{*}$ & 0.08 \\
\hline Buttock & 0.06 & $-0.35^{*}$ & 0.09 & 0.11 & 0.03 & 0.03 & 0.08 \\
\hline Calf & 0.07 & 0.02 & $-0.57^{*}$ & 0.08 & $0.35^{*}$ & $0.27^{*}$ & $0.43^{*}$ \\
\hline Knee & 0.09 & 0.09 & -0.17 & 0.07 & $0.26^{*}$ & $0.33^{*}$ & 0.14 \\
\hline Ankle & 0.12 & 0.08 & 0.04 & 0.02 & $0.22 *$ & 0.08 & 0.35 \\
\hline \multicolumn{8}{|l|}{ Somatotype } \\
\hline Endomorphy & 0.17 & $-0.33^{*}$ & $-0.21^{*}$ & $0.39^{*}$ & 0.03 & 0.02 & $-0.34 *$ \\
\hline Mesomorphy & 0.03 & $0.34 *$ & $0.29^{*}$ & 0.17 & 0.11 & 0.03 & $0.26^{*}$ \\
\hline Ectomorphy & 0.05 & 0.17 & -0.09 & $-0.41 *$ & 0.12 & 0.06 & 0.13 \\
\hline
\end{tabular}

Table 4. The relationship between the physical fitness and body compositions of male students

\begin{tabular}{|c|c|c|c|c|c|c|c|}
\hline & \multicolumn{7}{|c|}{ Male } \\
\hline & Flexibility & $\max \mathrm{VO} 2$ & $\begin{array}{l}20 \mathrm{~m} \\
\text { speed }\end{array}$ & $\begin{array}{l}\text { Right hand grip } \\
\text { strength }\end{array}$ & $\begin{array}{l}\text { Left hand grip } \\
\text { strength }\end{array}$ & $\begin{array}{c}\text { Leg } \\
\text { strength }\end{array}$ & Balance \\
\hline & $\mathrm{cm}$ & $\mathrm{ml} . \mathrm{kg} / \mathrm{min}$ & $\mathrm{sec}$ & $\mathrm{kg}$ & $\mathrm{kg}$ & $\mathrm{kg}$ & \\
\hline Height (cm) & $-0.52 * *$ & 0.11 & $-0.35^{*}$ & $0.61^{*}$ & $0.44 *$ & $0.39 *$ & $-0.68 * *$ \\
\hline Body weight $(\mathrm{kg})$ & -0.09 & $-0.44 *$ & -0.18 & $0.42 *$ & $0.44 *$ & 0.13 & 0.13 \\
\hline BMI (kg/m2) & -0.14 & $0.41^{*}$ & -0.19 & $0.35^{*}$ & $0.31 *$ & 0.09 & 0.07 \\
\hline Body fat percentage (\%) & -0.13 & $-0.36^{*}$ & 0.05 & $0.24 *$ & $0.28 *$ & 0.14 & 0.08 \\
\hline \multicolumn{8}{|l|}{ Length measurements (cm) } \\
\hline Sitting height (bust length) & 0.07 & 0.08 & $-0.49^{* *}$ & $0.48^{*}$ & $0.35^{*}$ & $0.49 *$ & -0.36 \\
\hline Arm & 0.18 & 0.03 & $-0.55^{*}$ & $0.51 * *$ & $0.29 *$ & $0.37 *$ & 0.11 \\
\hline Forearm & 0.06 & 0.02 & $-0.45^{*}$ & $0.42 *$ & $0.44 *$ & $0.42 *$ & 0.13 \\
\hline Leg & $-0.47^{*}$ & 0.11 & $-0.61^{* *}$ & $0.61^{*}$ & 0.43 & $0.59 *$ & -0.26 \\
\hline Thighs & $-0.38^{*}$ & 0.12 & $-0.39 *$ & $0.42 *$ & 0.35 & $0.42 *$ & -0.28 \\
\hline
\end{tabular}




\begin{tabular}{|c|c|c|c|c|c|c|c|}
\hline \multicolumn{8}{|c|}{$\begin{array}{l}\text { Circumference measurements } \\
\text { (cm) }\end{array}$} \\
\hline Elbow & 0.18 & 0.15 & 0.28 & $0.36^{*}$ & $0.43^{*}$ & 0.14 & 0.06 \\
\hline Shoulder & 0.09 & 0.03 & 0.09 & $0.48^{*}$ & $0.47^{*}$ & 0.14 & 0.07 \\
\hline Biceps (flexion) & 0.06 & 0.04 & $-0.53^{*}$ & $0.41^{*}$ & $0.57 * *$ & 0.09 & 0.09 \\
\hline Waist & 0.04 & 0.11 & 0.11 & 0.11 & 0.08 & 0.05 & 0.16 \\
\hline Buttock & 0.15 & $-0.35^{*}$ & $0.41^{*}$ & 0.18 & 0.17 & 0.07 & -0.12 \\
\hline Calf & 0.16 & 0.08 & $-0.57^{*}$ & 0.05 & $0.41 *$ & $0.48^{*}$ & $0.32 *$ \\
\hline Knee & 0.11 & 0.04 & 0.13 & 0.07 & $0.32 *$ & $0.59 * *$ & 0.08 \\
\hline Ankle & 0.05 & 0.03 & 0.12 & 0.08 & 0.14 & $0.46^{*}$ & $0.27 *$ \\
\hline \multicolumn{8}{|l|}{ Somatotype } \\
\hline Endomorphy & 0.08 & $-0.33 *$ & $-0.31 *$ & $0.29 *$ & 0.19 & 0.08 & 0.07 \\
\hline Mezomorphy & 0.11 & 0.05 & $0.29 *$ & $0.18^{*}$ & 0.13 & 0.11 & $0.19^{*}$ \\
\hline Ectomorphy & 0.18 & 0.36 & 0.17 & 0.10 & 0.21 & 0.12 & 0.08 \\
\hline
\end{tabular}
$* \mathrm{P}<0.05$.

\section{Discussion}

In literature, although there are many studies on anthropometric measurements, somatotype, body composition and physical fitness in many different branches, in terms of people of different ages who do sports (Bortoni \& Bojikian, 2007; K1lınç, 2008; Mahdi, 2013; Avar \& Akça, 2013; Dimitric et al., 2016; Popoyici et al., 2017; Şentürk et al., 2017), there are very few studies on the body composition of children who do not do sports in this age group and the relationship between length and circumference measurements and physical parameters (Pissanos et al., 1983; Okely et al., 2003; Ayan, 2008).

In this study, a statistically significance relationship has been found between male and female students in all parameters with the exception of age and arm, forearm, leg, thigh length and ankle circumference measurements $(p<0.05)$. The height, body weight, BMI, body fat percentage and waist circumference has been found higher in female students compared to male students. The male students' max VO2, vertical jump, right-left hand grip strength, leg strength and speed parameters and the female students' flexibility and balance parameters have been found to be higher and a statistically significant relationship has been observed between them $(p<0.05)$. It can be stated that this is an expected result for children who are in their adolescence period. Bostanc1 et al. (2017), in their study on young swimmers, have found out that female children have a higher ratio of body fat compared to male children and diameter, length and circumference measurements are either similar in female and male children or female children have higher averages. The anthropometric measurements display differences in female and male children during adolescence period. Sitting height reaches its highest increase value in ages 11-12 in female children and 13-14 in male children, while full leg length reaches its highest increase value in ages 10-11 in female children and 11-12 in male children. Besides this being a developmental characteristic related to this period, ages 11-12 are the beginning of puberty for female children; therefore, it is natural that female children develop faster compared to male children. However, in ages 13-14 and later on, these values change in the favor of male children and the difference increases (Martinez et al., 2013).

In female children, a negative relationship was found between flexibility and height, sitting height, full arm and forearm values, whereas in male children, a negative relationship was found between flexibility and height, leg and thigh length values. According to this result, we can say that flexibility performance does not get much affected from anthropometric characteristics. In Pekel et al.'s (2006) study on athletes, a relationship was not found between the results of flexibility test and anthropometric characteristics and in Pissanos et al.'s (1983) study on 80 students, it was determined that flexibility changes in line with gender and that there is a relationship between body composition and strength and cardiovascular function.

In female children, a negative relationship was found between max VO2 and BMI and between body fat percentage, hip circumference value and endomorphy and a positive relationship with mesomorphy, whereas a negative relationship was found between max $\mathrm{VO}_{2}$ and $\mathrm{BMI}$ and body weight, BMI, body fat percentage, hip circumference and endomorphy value. In both genders, as BMI, body fat percentage and endomorphy increases, the performance gets affected negatively. Okely et al. (2003), in their study on the six basic movement skills of children and teenagers (running, vertical jumping, throwing, catching, kicking and striking) and height, weight, BMI and waist circumference, have found out that there is a negative relationship between these six basic movements and BMI and waist circumference. 
Speed is an important motor characteristic which determines productivity in numerous sports. The most suitable exercise periods for the development of speed are school and puberty periods (Oğuzhan et al., 2014; Zorba \& Saygin, 2009). In this study, a negative relationship has been found between $20 \mathrm{~m}$. Speed value and height, sitting height, full arm, forearm, full leg, thighs, biceps in flexion, calf circumference and endomorphy; a positive relationship has been found between $20 \mathrm{~m}$. Speed and mesomorphy; a negative relationship between $20 \mathrm{~m}$. Value and height, sitting height, full arm, forearm, full leg, thighs, biceps in flexion, calves and endomorphy values in male children and a positive relationship between $20 \mathrm{~m}$. Speed and mesomorphy value. It was seen in this study that length and circumference measurements affects speed in both genders.

In female children, there is a positive relationship between right hand grip strength and height and height and between body weight, BMI, body fat percentage, sitting height, arm, forearm, leg, thighs, elbow width, shoulders, biceps in flexion value and endomorphy and a negative relationship between ectomorphy; in male children, a positive relationship was found between right hand grip strength and height and body weight, BMI, body fat percentage, sitting height, arm, forearm, leg, thighs, elbow width, shoulders and biceps (flexion) and mesomorphy and endomorphy. In female children, a positive relationship was found between left hand grip strength and height and body weight, BMI, body fat percentage, sitting height, arm, forearm, leg, thighs, elbow width, shoulders, biceps in flexion, calves, knees and ankles; in male children, a positive relationship was found between left hand grip strength and height and body weight, BMI, body fat percentage, sitting height, arm, forearm, elbow width, shoulders, biceps (flexion), calf, knee circumference. Grip strength is a physiological variable which is affected by a series of factors such as age, gender and body height. There is a strong relationship between grip strength and various anthropometric characteristics (weight, height, hand length, etc.) (Jürimäe et al., 2008; Singh et al., 2009; Koley et al., 2009; Kaur, 2009).

There is a positive relationship between leg strength and height, sitting height, arm, forearm, leg, thighs, elbow width, biceps in flexion, calf, and knee circumference in female children and there is a positive relationship between leg strength and height, sitting height, arm, forearm, leg, thighs, calf, knee and ankle circumference in male children. It has been observed that muscle strength in children and adolescents significantly increase with age and the greatest development takes place in puberty. Body size, body structure and composition are the important factors which affect strength and performance (Muratl1, 2003).

In female children, a negative relationship was found between balance and height, body weight, body fat percentage, sitting height, leg, thighs and endomorphy values and a positive relationship between calf circumference values, where as in male children, a negative relationship was found between balance and height and a positive relationship was found between calf, ankle and mesomorphy. Erdoğan and Karatoprak (2017) have found a positive relationship between mesomorph and balance in their study on athlete children.

Behdari et al. (2016) have found a stable negative relationship between endomorphy and performance and that the relationship between ectomorphy and performance is changeable and that it is low in general. Ayan (2008) has found a negative relationship between endomorphy and vertical jumping; a positive relationship between endomorphy and 20 m speed; a negative relationship between mesomorphy and vertical jumping; a positive relationship between mesomorphy and $20 \mathrm{~m}$. run; a positive relationship between ectomorphy and vertical jumping and a negative relationship between ectomorphy and $20 \mathrm{~m}$ speed.

It can be stated that for children who are to be directed towards a sports branch to be the best candidates in terms of sportive and sports skills with the best anatomical structure, somatotypes are important criteria (Özbek, 1979). In this study, it has been seen that increase in endomorphy negatively affects performance in female and male students. The motor performances and motor skills of children get greatly affected by regular exercise. In addition, regular exercise positively affects the children's somatotype classification and anthropometric characteristics (Polat et al., 2003).

In Polat et al.'s (2003) study on athletes and sedentary individuals, it has been determined that the averages of the athletes were higher in terms of shoulder, bust, thigh, calf, biceps extension and flexion circumference values, whereas the waist circumference values of sedentary individuals were higher in average. İncreases in circumference in large and small muscle groups in the extremities shows that they are greatly affected by exercise.

\section{Conclusion}

In this period in which motor characteristics increase with age, identification of body composition is extremely important in the healthy development of children and directing them towards participation in sports. Regularly carrying out anthropometric measurements, children's follow up and evaluation carry great importance for the identification of skilled athletes and sustainable success (Bostanc1 et al., 2017). As a result, children in this age group should be observed by their teachers, their anthropometric measurement and performance tests should be 
carried out regularly and they should be directed towards suitable sports branches.

\section{References}

Artioli, G. G., Gualano, B., Franchini, E., Batista, R. N., \& Polacow, V. O. (2008). Lancha AH. Physiological, performance, and nutritional profile of the brazilian olympic wushu (kung-fu) team. Journal of Strength and Conditioning Research, 1-6.

Avar, P., \& Akça, F. (2013). 10-12 Yaş Grubu Tenisçilerin Türkiye Klasman Siralamalarına Göre Antropometrik Özellikleri ve Servis Hızlarının İncelenmesi. Spormetre Beden Eğitimi ve Spor Dergisi, 11(1), 35-40.

Ayan, A. (2008). 8-10 yaş grubu kız çocuklarının antropometrik, somatotip ve bazı performans özelliklerinin incelenmesi. New World Sciences Academy, 3(2), 36-42.

Behdari, R., Zorba, E., Göktepe, M., \& Bayram, M. (2016). 9-12 yaş masa tenisçilerin vücut kompozisyonu, antropometrik ve somatotip özelliklerinin belirlenmesi. Sportif Bakış: Spor ve Eğitim Bilimleri Dergisi, 3(1), 61-69.

Berg, K. E., Lavoie, J. C., \& Latin, R. W. (1995). Physiological training effect of youht soccer. Medicine Science Sports Exercise, 17(6), 656-60.

Bortoni, L. W., \& Bojikian, L. (2007). Growth and physical fitness of male students in sporting initiation. Brazilian Journal of Biomotricity, 1(4), 114-122.

Bostanc1, Ö., Ateş, A., Yılmaz, A. K., \& Kabaday1, M. (2017). 12-13 yaş yüzücülerin cinsiyetlerine göre antropometrik özelliklerinin karşılaştıılması. Inönü Üniversitesi Beden Eğitimi ve Spor Bilimleri Dergisi, 4(3), 12-21.

Canhadas, I. L., Lopez, R., Silva, P., Rodrigures, C., Leslie, C., \& Portes, A. (2010). Anthropometric and physical fitness characteristics of young male soccer players. Brasilian Journal of Kinanthropometry, 12(4), 239-245. http://dx.doi.org/10.5007/1980-0037.2010V12N4P239

Çolak, H., \& Yiğit, Z. (2017). Investigating the changes on body composition in women regularly exercise. Journal of Current Researches on Health Sector, 7(2), 70-78. http://dx.doi.org /10.26579/jocrehes_7.2.6

Cordova, A., Villa, G., Sureda, A., Rodriques-Marrovo, J. A., \& Sanchez-Collado, M. P. (2012). Physical activity and cardiovascular risk factors in spanish children aged 11-13 years. Revista Espanola de Cardiologia, 65(7), 620-626. http://dx.doi.org /620-626.10.1016/j.rec.2012.01.028

Dimitric, G., Cokorilo, N., \& Bogdanovski, M. (2016). Relations between anthropometric characteristics and motor abilities of 14-15u female swimmers on 50m result for each technique. Sport Mont, 14(3), 37-40.

Docherty, D. (1996). Measurement in Pediatric Exercises Sciense. Human Kinetics, Champaign, IL.

Erdoğan, E., \& Karatopak, T. (2017). Altyapı Sporcularında Somatotip Özellikler İle Anaerobik Performans ve Dinamik Denge Arasındaki İlişsi. Dünya Spor Bilimleri Araştırmaları Kongresi, Manisa, s517.

Günay, M., Tamer, K., \&Cicioğlu, İ. (2013). Spor Fizyolojisi ve Performans Ölçümü (3. Baskı). Ankara, Gazi Kitabevi.

Jürimäe, T., Voracek, M., Jürimäe, J., Lätt, E., Haljaste, K., Saar M., \& Purge, P. (2008). Relationships between Wnger-length ratios, ghrelin, leptin, IGF axis, and sex steroids in young male and female swimmers. Europen Journal of Applied Physiology, 104, 523-529. https://doi.org/10.1007/s00421-008-0801-z

Kaur, M. (2009). Age-related changes in hand grip strength among rural and urban Haryanvi Jat females. Journal of Comparative Human Biology, 60, 441-450. https://doi.org/10.1016/j.jchb.2009.06.002

Kılınç, F. (2008). Çocuklarda ekstiremite uzunluk ve çevre ölçümlerinin kürek çekme performansı üzerine etkileri, S.D.Ü. Tıp Fak. Dergisi, 15(3), 30-33.

Koley, S, Kaur, N., Sandhu, J. S. (2009). Association of hand grip strength and some anthropometric traits in female labourers of Jalandhar, Punjab, India. Journal of Life Science, 1, 57-62. https://doi.org/10.1080/09751270.2009.11885135

Mahdi, E. (2013). Prediction of playing ability in wrestle using antropometrical and physical variables among college level players. Life Science Journal, 10(4s), 331-333.

Martínez, S., Pasquarelli, B., N., Romaguera, D., Arasa, C., Tauler, P., \& Aguiló, A. (2011). Anthropometric characteristics and nutritional profile of young amateur swimmers. The Journal of Strength \& Conditioning Research, 25(4), 1126-1133. 
Muratlı, S. (2009). Çocuk ve Spor Antrenman Bilimi Yaklaşımıyla, 1. Baskı, Nobel Yayın Dağıtım, Ankara.

Oğuzhan, Y., Kemal, T., \& Gökhan, Ç. (2014). Evaluate the physical fitness levels of turkish primary school male and female children between 7-14 ages. Science, Movement and Health, 14(2), 585-593.

Okely, A. D., Booth, M. L., \& Chey, T. (2003). Relationships between Body Composition and Fundamental Movement Skills among Children and Adolescents. Research Quartely for Exercise and Sport, 75(3), 238-247. https://doi.org/10.1080/02701367.2004.10609157

Özbek, M. (1979). İnsan ve Irk, Remzi Kitap Evi, İstanbul.

Özer, K. M., \& Özer, D. S. (2000). Çocuklarda Motor Gelişim, Kazancı Kitap Tic. A.Ş., 230, İstanbul.

Pekel, H., Bağcı, E., Güzel, N. A., Onay, M., Balcı, Ş. S., \& Pepe, H. (2006). Spor yapan çocuklarda performansla ilgili fizikseluygunluk test sonuçlarıyla antropometrik özellikler arasındaki ilişkilerin değerlendirilmesi. Kastamonu Eğitim Dergisi, 14(1), 299-308.

Pissanos, B. W., Moore, J. B., \& Reeve, T. G. (1983). Age, sex, and body composition as predictors of children's performance on basic motor abilities and health-related fitness items. Perceptual and Motor Skills, 56(1), 71-77. https://doi.org/10.2466/pms.1983.56.1.71

Polat, Y., Çınar, V., Şahin, M., \& Pepe, O. (2003). 14 yaş çocukların fiziksel uygunluk düzeyleri ile antropometrik özelliklerinin incelenmesi. İ.Ü. Spor Bilimleri Dergisi, 11(3), 127-130-137.

Popovici, I. M., Popescu, L., \& Radu, L. E. (2017). Evaluation of some physical fitness characteristics in 11-13 years old. Cypriot Journal of Educational Sciences, 12(1), 09-13.

Reicherte, F. F., Menezes, A., Hallal, P., Ekelund, U., \& Wells, J. (2012). Objectively measured physical activity and body composition indices in Brazilian adolescents. Brazilian Journal of Physical Activity and Health, 17(6), 573-584. http://dx.doi.org/10.12820/2317-1634.2012v17n6p573

Şentürk, A., Öktem, G., \& Şanslı, S. (2017). Analyzing the anthropometric and performance features of 16-18 years-old female wrestling and karate athletes. International Journal of Science Culture and Sport, 5(1), 27-34. http://dx.doi.org /10.14486/IntJSCS643

Shahtahmasebi, S., \& Cassidy, B. (2015). Women's perception of body shape/weight and health: a measurement problem. International Children Adolescent Health, 8(3).

Singh, A. P., Koley, S., \& Sandhu, J. S. (2009). Association of hand grip strength with some anthropometric traits in collegiate population of Amritsar. Orient. Anthropology, 9, 99-110.

Zorba, E., \& Saygın, Ö. (2009). Physical Activity and Physical Fitness. İnceler Offset, İstanbul.

\section{Copyrights}

Copyright for this article is retained by the author(s), with first publication rights granted to the journal.

This is an open-access article distributed under the terms and conditions of the Creative Commons Attribution license (http://creativecommons.org/licenses/by/4.0/). 